\title{
Meningkatkan Hasil Belajar Pendidikan Agama Islam dengan Instrumen Permainan Bendera di Kelas I SD Negeri 09 Kepahiang
}

\author{
Fajaria \\ SD Negeri 09 Kepahiang \\ fajaria.ix@gmail.com
}

\begin{abstract}
Islamic Education in elementary schools introduces students to aspects of the Islamic religion itself, ranging from the Al-Qur'an, recognize the aspects of the pillars of Islam, faith in Alah, to the Qadha and Qadar. Be lauded in everyday life and avoid reprehensible behavior. Get to know and implement the pillars of Islam that starts from the recitation of the shahada to find out the procedures for performing the Hajj. Tell the stories of the prophets and take an example from these stories and tell the story of despicable people in everyday life. All of that will be the provision of the students later. But all aspects will be difficult for students to digest if conveyed in a less conventional way. For this reason, a research is needed. This Classroom Action Research (CAR) has the intent and purpose of improving Islamic Education learning outcomes through the instrument of flag Permainan. This research was conducted in two cycles. The participants in this study were grade 1, students at SD Negeri 09 Kepahiang. The number of students is 29 children. The data collection method uses teacher activity observation sheets, student activities and tests to get data on learning outcomes. The results and data obtained from Cycle I and Cycle II emphasize that by using the Flag Game instrument, a significant increase in learning outcomes was found with good scores and very good grades, from initially only $48.1 \%$ to $92.8 \%$.
\end{abstract}

Keywords: Islamic Education, Learning Outcomes, Flag Games

\begin{abstract}
Abstrak
Pendidikan Agama Islam di Sekolah Dasar memperkenalkan siswa pada aspek-aspek Agama Islam itu sendiri, mulai dari Al-Qur'an, mengenal aspek-aspek rukun Islam dan iman kepada Allah, sampai dengan kepada Qadha dan Qadar. Berperilaku terpuji dalam kehidupan sehari-hari serta menghindari perilaku tercela. Mengenal dan melaksanakan rukun Islam yang dimulai dari bacaan dua kalimat syahadat sampai mengetahui tata cara pelaksanaan ibadah haji. Menceritakan kisahkisah nabi-nabi serta mengambil teladan dari kisah-kisah tersebut dan menceritakan kisah orang-orang tercela dalam kehidupan sehari-hari. Kesemua itulah yang akan menjadi bekal para siswa nantinya. Tetapi kesemua aspek itu akan sukar dicerna oleh siswa apabila di sampaikan dengan cara yang kurang konvensional. Untuk itu perlu di adakan sebuah penelitian. Penelitian Tindakan Kelas (PTK) ini mempunyai maksud dan tujuan untuk Meningkatkan Hasil Belajar Pendidikan Agama Islam melalui Instrumen Permainan Bendera. Penelitian ini dilaksanakan dalam dua siklus. Adapun partisipan dalam penelitian ini adalah siswa kelas I SD Negeri 09 Kepahiang. Jumlah siswa sebanyak 29 anak. Metode pengumpulan data menggunakan lembar observasi aktifitas guru, aktifitas siswa dan tes untuk mendapatkan data hasil
\end{abstract}


belajar. Hasil dan data yang diperoleh dari Siklus I dan Siklus II menekankan bahwa dengan menggunakan instrumen Permainan Bendera, ditemukan sebuah peningkatan hasil belajar yang sangat signifikan dengan jumlah nilai baik dan nilai amat baik dari yang awalnya hanya $48,1 \%$ menjadi sebesar $92,8 \%$.

\section{Kata Kunci: Pendidikan Agama Islam, Hasil Belajar, Permainan Bendera}

\section{Pendahuluan}

Berdasarkan pengalaman selama mengajar siswa Kelas I jenjang Sekolah Dasar untuk Pendidikan Agama Islam dijumpai siswa masih terlihat mengalami kesulitan, salah satunya adalah sulitnya siswa dalam menghafal surat-surat yang terdapat dalam Al-Qur'an. Metode hafalan yang sebelumnya sudah dipraktekkan mempunyai banyak kekurangan, sehingga siswa kesulitan dalam mengurutkan dan melafalkannya. Selain itu, faktor lainnya, masih banyak siswa yang belum lancar bahkan belum tahu cara membaca Al-Qur'an. Ini kemungkinan bisa disebabkan karena siswa belum pernah diperkenalkan kepada Al-Qur'an serta kegunaan dan fungsi hafalan surat-surat dalam menunaikan Sholat.

Al Fatihah (2016) mengungkapkan prestasi belajar adalah tolak ukur dalam menentukan keberhasilan suatu pembelajaran. Tak terkecuali mata pelajaran Pendidikan Agama Islam. Terkait dengan hasil atau prestasi itulah sebagai peneliti bisa didapatkan bahwa tidak semua siswa memliki tingkatan atau taraf pemahaman yang baik mengenai suatu pelajaran. Dan dilain pihak tak hanya problem datang dari siswa tetapi menurut Nurlina, dkk (2014) Dalam kenyataan banyak sekali yang terjadi di lapangan tentang pembelajaran yang belum terlaksana sesuai dengan manajemen pengajaran karena sebagian guru masih belum dapat mengikuti prosudurm pengajaran yang telah ditetapkan dan tidak terlalu memahami tentang peranan manajemen dalam pengajaran. Maka daripada itu, sebuah solusi harus digunakan.

Untuk mengatasi permasalahan tersebut, perlu dilakukan penerapan pembelajaran melalui Permainan (permainan) Bendera agar siswa mudah mempelajari dan mengingat surat-surat pendek Al-Qur'an yang akan meningkatkan hasil belajar. Setiap siswa seusia kelas I Sekolah Dasar selalu ingin bermain. Bermain merupakan sesuatu yang menyenangkan bagi siswa terutama yang berusia dini. Hampir tidak ada permainan yang membuat siswa tidak merasa senang. Bermain dapat terjadi lama-lama namun juga dapat ia lakukan sesaat atau sebentar.

Bermain sangat penting bagi tumbuh kembang seorang anak. Bermain adalah salah satu cara dalam membantu pengembangan karakter dan berbagai aspek pada anak usia dini. Menurut Piaget (1951) bermain merupakan kegiatan yang dilakukan berulang-ulang demi kesenangan. Sedangkan Freeman dan Munandar (1996) juga menyampaikan bahwa dengan bermain dapat membantu anak mencapai perkembangan yang utuh, baik secara fisik, sosial, intelektual, moral dan emosional.

Dananjaya (2012) menyarankan daur belajar pengalaman tentang bagaimana mengembangkan permainan. Berdasarkan daur belajar tersebut dikembangkan suatu permainan yang disebut Permainan Bendera. Permainan Bendera ini dikembangkan dan diberi sedikit senutuhan modifikasi dari instrumen yang digunakan oleh Aprilianti (2017) yang mana dalam jurnalnya menjelaskan permainan bendera pintar ialah permainan yang dikolaborasikan antar membilang dengan sebuah alat berbentuk bendera yang telah dimodifikasi sesuai dengan kebutuhan, dimana disetiap bendera telah diberikan nomor dari 1-20. Hal itu untuk 
mengembangkan kemampuan membilang 1-20 pada anak usia dini melalui permainan.

Dan dalam penelitian ini Permainan Bendera diberi sedikit perubahan untuk pelajaran Pendidikan Agama Islam, yaitu: (1) Membentuk kelompok belajar; (2) Memberikan kesempatan kepada perwakilan kelompok untuk mengambil Bendera sesuai urutan ayat; (3) Memberikan kesempatan kepada anggota kelompok untuk mengurutkan Bendera sesuai urutan ayat; (4) Memberikan kesempatan kepada anggota kelompok untuk membaca urutan ayat dengan keras; (5) Setelah dibacakan disusun di meja sebagai bahan untuk dihafalkan; dan (6) Siswa yang lebih mampu dapat memandu temannya.

Penggunaan Permainan Bendera ini sendiri juga diteliti oleh Sulasmi (2014) didalam jurnalnya mengungkapkan, peserta didik melalui bermain dan belajar memberikan suasana lebih meriah, aktif dan berani tampil, yang berbeda dibandingkan dari metode yang dilakukan oleh guru sebelumnya.

\section{Metode}

Metode yang digunakan dalam Penelitian Tindakan Kelas ini mengikuti model penelitian yang diperkenalkan oleh Kemmis \& McTaggart dalam Nurmayanti, dkk (2017) yang mencakup 4 komponen yaitu: (1) Perencanaan; (2) Pelaksanaan, (3) Observasi, (4) Refleksi. Menurut Hasanuddin dan Arief (2018) Keempat komponen tersebut membentuk suatu siklus dan dalam pelaksanaanya kemungkinan membentuk lebih dari satu siklus yang mencakup keempat komponen tersebut. Model Kemmis \& McTaggart adalah salah satu model yang paling populer dan paling tepat dalam Penelitian Tindakan Kelas. Dan pada saat semua persiapan sudah matang langkah selanjutnya adalah perencanaan yang sudah dianalisis dan direvisi, pelaksanaan tindakan, pengamatan terhadap partisipan dan lingkungan sekitar, dan refleksi atas hasil data. Sebelum memasuki Siklus I perlu dilakukan tindakan awal yang berupa identifikasi permasalahan, yang mana tindakan ini bisa dilakukan dengan sebuah tes permulaan

Penelitian ini mengambil tempat di SD Negeri 09 Kepahiang. Partisipan dalam penelitian ini adalah siswa Kelas I Semester Genap tahun pelajaran 2019/2020. Siswa kelas I berjumlah 20 orang terdiri dari 8 orang laki-laki, dan 12 orang perempuan.

Dalam penelitian ini instrumen yang digunakan terdiri dari: lembar observasi untuk mengamati pelaksaanan guru dalam melakukan Permainan Bendera; Lembar observasi untuk mengamati kegiatan dan aktifitas siswa saat mengikuti pembelajaran dengan Permainan Bendera; dan tes yang digunakan untuk mengetahui peningkatan hasil belajar siswa terhadap materi yang dipelajari selama penelitian berlangsung.

Teknik pengumpulan data yang digunakan adalah teknik observasi dan tes tulis. Observasi menurut Riduwan dalam Ayudia, Suryanto dan Waluyo (2016) merupakan teknik pengumpulan data, di mana peneliti melakukan pengamatan secara langsung ke objek penelitian untuk melihat dari dekat kegiatan yang dilakukan. Sedangkan Tes Tulis yang digunakan berbentuk uraian. Menurut Kunandar dalam Muttaqin dan Kusaeri (2017) Tes tertulis bentuk uraian merupakan seperangkat soal yang berupa tugas, pertanyaan yang menuntut peserta didik untuk mengorganisasikan dan menyatakan jawabannya menurut kata-kata sendiri. Jawaban tersebut dapat berbentuk mengingat kembali, menyusun, mengorganisasikan atau memadukan pengetahuan yang telah dipelajarinya dalam rangkaian kalimat atau kata-kata yang tersusun secara baik. Penelitian yang menggunakan teknik ini memiliki tujuan 
untuk meningkatkan hasil belajar siswa pada Pendidikan Agama Islam, dan teknik yang tesrebut diatas sangat tepat lebih-lebih dalam penlitian tindakan kelas.

Analisis pelaksanaan pembelajaran dengan menggunakan metode Permainan Bendera surat-surat pendek. Data pelaksanaan pembelajaran yang terdapat pada lembar observasi pelaksanaan pembelajaran yang berupa aktifitas guru dan aktifitas siswa, catatan lapangan dianalisis secara deskriptif setiap siklus. Menurut Sudjana dalam Anegawati (2016) yang dimaksud dengan analisis deskriptif adalah usaha melukiskan dan menganalisis kelompok yang diberikan tanpa membuat atau menarik kesimpulan dari populasi lebih besar. Hal ini bermanfaat untuk rencana perbaikan pembelajaran pada siklus berikutnya. Untuk menentukan keberhasilan pembelajaran dengan menggunakan Permainan Bendera dari hasil pengamatan kolaborator dari keterlaksanaan tahapan-tahapan Permainan Bendera dan catatancatatan dari kolaborator untuk acuan refleksi.

\section{Hasil}

Dalam pelaksanaannya Penelitian Tindakan Kelas yang dikerjakan ini diterapkan dalam dua siklus dengan kompetensi dasar menghafal surat An-Nasr dan surat $A l$ 'Ashr. Langkah-langkah yang dilakukan adalah sebagai berikut.

\section{Siklus I}

\section{A. Perencanaan}

Kegiatan yang dimulai dari tahap perencanaan Siklus I adalah sebagai berikut. 1. Membuat perencanaan pembelajaran yang terdiri dari Silabus dan RPP; 2 . Merancang langkah-langkah pembelajaran atau metode yang akan dilaksanakan dalam pembelajaran; 3. Membuat instrumen monitoring untuk mengamati aktifitas guru dan siswa didalam kelas selama proses pembelajaran; 4. Menyiapkan media atau instrumen, serta sarana pembelajaran yaitu Bendera surat An-Nasr dan surat Al-Ashr; kemdudian 5. Membuat instrumen evaluasi untuk meengukur tingkat hasil belajar pada siswa di evaluasi awal dan dilanjutkan nantinya pada evaluasi akhir yang dilaksanakan disetiap siklus.

Adapun pada pelaksanaan Siklus I ini, Kompetensi Dasar yang ingin dicapai dengan menggunakan Instrumen Permainan Bendera adalah menghafal surat An-Nasr dan surat Al'Ashr.

\section{B. Tindakan/Pelaksanaan}

Pada pelaksanaan Siklus I digunakanlah pembelajaran Permainan Bendera surat An-Nasr dengan cara berikut: Guru meberikan motivasi kepada siswa dengan menanyakan apakah mereka sudah mengenal dan mendengar tentang surat-surat pendek yang terdapat dalam Al-Qur'an atau mereka sudah hafal dengan surat $A t$ Takasur. Siswa yang hafal, diberi kesempatan untuk menunjukkan hasil hafalannya kepada siswa yang lain. Pada pertemuan pertama di Siklus I, guru meminta dan sekaligus membantu mengelompokkan siswa menjadi 5 kelompok agar mempermudah siswa dalam menghafal. Guru menujukkan contoh bacaan surat An Nasr, siswa menirukan dan diulang-ulang sampai tiga kali.

Guru menunjukkan media Bendera surat An-Nasr yang berjumlah tiga Bendera yang memuat masing-masing 1 ayat. Kemudian guru meminta perwakilan dari anggota kelompok satu, anggota kelompok dua dan anggota kelompok tiga maju kedepan untuk mengambil Bendera satu anggota kelompok. Pelaksanaannya siswa maju semua berebut untuk mengambil Bendera. Kemudian guru menjelaskan bahwa yang maju satu kelompok hanya satu orang, anggota yang lain duduk di kursi masing-masing untuk membaca urutan Bendera surat An-Nasr. Guru memanggil satu orang dari kelompok satu, dua, dan tiga untuk maju kedepan agar dapat memegang Bendera, kemudian membantu mengurutkan sesuai dengan urutan ayat 
benar. Kemudian perwakilan dari masing-masing kelompok memegang dan membacakan ayat yang ada di Bendera dan diikuti oleh semua siswa didalam kelas.

Kemudian, guru memberikan surat An-Nasr yang kembali dibagi menjadi tiga Bendera, agar siswa dapat menyusunnya di meja sehingga urutannnya menjadi benar. Ternyata ditemukan sejumlah kelompok yang penyusunan urutannya masih salah. Siswa diberi tugas menghafalkan untuk semua anggota kelompok masingmasing. Bagi siswa yang telah hafal guru akan meminta mereka untuk membantu menjadi tutor sebaya dikelompoknya.

Pada pelaksanaan Siklus I, siswa telah melaksanakan tugas-tugas yang diberikan oleh guru. Dan dari Tahap Observasi masih ditemukan siswa yang acuh terhadap tugas yang diberikan, ada yang asyik bermain-main, ada yang sibuk mengobrol, bahkan ada yang menolak untuk diajari oleh temannya yang sudah hafal. Guru kemudian mendatangi kelompok-kelompok yang masih belum mau mengikuti pelajaran dengan serius untuk memberikan pengarahan, penjelasan dan bimbingan.

Selama 2 jam penelitian dan pelajaran berlangsung, hanya dua siswa yang sudah dapat menghafal. Akhirnya, kegiatan hafalan akan dilanjutkan dalam pertemuan kedua. Pada tahap Refleski Guru mengecek kesiapan siswa dalam menghafal surat An-Nasr dengan cara menghafal bersama-sama. Setelah itu siswa menghafal dengan kelompok masing-masing, anggota kelompok yang sudah hafal mengajari anggota kelompoknya yang belum hafal. Setelah itu siswa menghafal satu persatu, guru mencatat kemampuan siswa dalam menghafal sambil memberikan bimbingannya terutama pada siswa yang belum hafal bacaan surah An-Nasr. Siswa yang mendapat nilai tertinggi diberikan penghargaan atau hadiah. Hal ini dilakukan untuk meningkatkan motivasi agar siswa lebih giat belajar.

\section{Siklus II}

Pada Siklus II, pembelajaran yang dilakukan pada mata pelajaran Pendidikan Agama Islam, adalah pembelajaran dengan kompetensi dasar menghafal Al-Qur'an surat An-Ashr dengan lancar, dilaksanakan 2 kali pertemuan (4 jam pelajaran) dengan langkah-langkah sebagai berikut:

\section{A. Perencanaan}

Tindakan yang akan dikerjakan di Siklus II ini masih tetap akan melakukan tindakan utama seperti pada Siklus I. Pada Siklus II ada beberapa hal yang akan dilakukan untuk memperbaiki kekurangan-kekurangan pada Siklus I. Adapun perubahan yang diperbaiki pada Siklus II antara lain sebagai berikut: 1. guru mengoptimalkan cara memotivasi siswa dalam menghafal; 2. guru memberikan bimbingan kepada kelompok maupun individu secara merata; 3. guru melakukan bimbingan dan dorongan kepada siswa agar dapat menghafal dengan maksimal; dan 4. guru menambahkan alokasi waktu untuk menghafal dengan mengubah jadwal yang harinya berurutan.

\section{B. Tindakan/Pelaksanaan}

Pada awal memulai pelajaran, guru menyampaikan kepada siswa tujuan pembelajaran yang akan dicapai, dimana tujuan itu adalah agar siswa hafal surat Al-Ashr dengan lancar dan benar. Guru memotivasi siswa untuk menguasai materi hafalan surat Al-Ashr agar dapat digunakan dalam mengerjakan sholat. Guru membentuk kelompok siswa menjadi 5 kelompok. Dalam pembelajaran yang dibantu dengan instrumen Permainan Bendera surat Al-Ashr ini, mempermudah siswa dalam menghafal. Pelaksanaan Siklus II pada pertemuan ini berdasarkan hasil pengamatan telah berjalan sesuai yang direncanakan.

Langkah-langkah pembelajaran sebagai berikut: Guru menunjukkan contoh bacaan surat $A l-A s h r$, siswa menirukan dan diulang-ulang sampai tiga kali. Guru menunjukkan Permainan Bendera surat $A l-A s h r$ yang dibagi menjadi tiga Bendera yang masing-masing memliki satu ayat. Guru menunjuk perwakilan kelompok satu, 
dua dan tiga untuk mengambil salah satu Bendera, tapi siswa maju semua berebut untuk mengambil Bendera. Kemudian guru menjelaskan bahwa yang maju, satu kelompok satu, anggota yang lain duduk dikursi masing-masing untuk membaca urutan Bendera sesuai urutan ayat surat Al-Ashr. Guru kembali menunjuk salah satu perwakilan dari kelompok satu, dua ,dan tiga untuk maju ke depan mengambil satu Bendera kemudian diurutkan sesuai urutan ayat surat Al-Ashr. Setelah urutannya sudah tepat, perwakilan dari masing-masing-kelompok membacakan ayat yang ada diBendera yang mereka pegang dan diikuti oleh seluruh anggota kelompok. Kemudian dilanjutkan kelompok lain sampai selesai semua kelompok.

Setelah itu guru menyerahkan Bendera surat Al-Ashr yang dibagi menjadi tiga ayat, agar disusun di meja masing-masing sesuai dengan urutannya. Ternyata masih ditemukan kelompok yang belum tepat alam mengurutkannya. Tiap-tiap kelompok diberi tugas menghafal dengan anggota kelompoknya masing-masing. Bagi siswa yang telah hafal, mereka diberikan tugas untuk membantu menjadi tutor sebaya dikelompoknya. Siswa telah melaksanakan tugas-tugas yang diberikan oleh guru. Namun, masih ditemupkan beberapa siswa yang masih acuh terhadap tugas yang diberikan, ada yang memilih mengobrol dengan temannya dan ada yang belum hafal tapi menolak ketika temannya mau membantu mengajarkan. Guru mendekati kelompok yang masih belum serius dalam pembelajaran, untuk memberikan pengarahan penjelasan dan bimbingan. Selama 2 jam pelajaran siswa belum bisa menghafal dengan benar dan lancar, baru 10 siswa yang mampu menghafal dengan lancar dan benar sehingga hafalan akan dilanjutkan pada pertemuan kedua. Pada pertemuan kedua Siklus II, guru mengecek daftar kehadiran untuk mengetahui siswa yang tidak hadir pada hari itu. Guru mengecek kesiapan siswa dalam menghafal surat $A l-A s h r$ dengan cara menghafal bersama-sama.

Setelah itu siswa menghafal dengan kelompok masing-masing, anggota kelompok yang sudah hafal mengajari anggota kelompok yang belum hafal. Setelah itu siswa menghafal satu persatu, guru mencatat kemampuan siswa dalam menghafal sambil memberikan bimbingan terutama pada siswa yang belum kesulitan dalam menhafal. Siswa yang mendapat nilai tertinggi diberikan penghargaan atau hadiah. Hal ini dilakukan untuk meningkatkan motivasi agar siswa lebih giat belajar.

\section{Pembahasan}

Pada pelaksanaan Siklus I, siswa telah melaksanakan tugas-tugas yang diberikan oleh guru. Namun masih ditemukan siswa yang acuh terhadap tugas yang diberikan, ada yang asyik bermain-main, ada yang sibuk mengobrol, bahkan ada yang menolak untuk diajari oleh temannya yang sudah hafal. Guru kemudian mendatangi kelompok-kelompok yang masih belum mau mengikuti pelajaran dengan serius untuk memberikan pengarahan, penjelasan dan bimbingan.

Selama 2 jam penelitian dan pelajaran berlangsung, hanya dua siswa yang sudah dapat menghafal. Akhirnya, kegiatan hafalan akan dilanjutkan dalam pertemuan kedua. Guru mengecek kesiapan siswa dalam menghafal surat An-Nasr dengan cara menghafal bersama-sama. Setelah itu siswa menghafal dengan kelompok masingmasing, anggota kelompok yang sudah hafal mengajari anggota kelompoknya yang belum hafal. Setelah itu siswa menghafal satu persatu, guru mencatat kemampuan siswa dalam menghafal sambil memberikan bimbingannya terutama kepada siswa yang belum mampu menghafal bacaan surah An-Nasr. Siswa yang mendapat nilai tertinggi diberikan penghargaan atau hadiah. Hal ini dilakukan untuk meningkatkan motivasi agar siswa lebih giat belajar.

Berdasarkan hasil pengamatan, aktifitas guru saat kegiatan pembelajaran Pendidikan Agama Islam dengan Permainan Bendera di Siklus I berlangsung, masih ditemukan beberapa kekurangan yaitu: 1. Pada saat materi disampaikan, guru masih kurang begitu jelas dan tepat dalam menyampaikan arahan, sehingga masih 
ditemukan siswa yang masih belum hafal surat An-Nasr ; 2 . Guru belum tepat sasaran disaat memberikan bimbingan kepada kelompok dikarenakan ketika guru membimbing kelompok tertentu, kelompok lain masih ada yang ribut; 3. Guru masih kurang dalam memberikan arahan kerja kelompok sebelum kerja kelompok dilaksanakan; 4. Guru kurang melaksanakan bimbingan secara maksimal untuk semua kelompok; 5) Guru kurang memperhatikan kelompok-kelompok yang belum lancar membaca; dan 6. Guru kurang memberikan bimbingan kelompok yang sering bermain-main.

Hasil pengamatan terhadap aktifitas siswa dalam kegiatan pembelajaran menggunakan Permainan Bendera surat An-Nasr pada Siklus I secara umum masuk dalam katagori baik. Tetapi ada beberapa kegiatan siswa yang belum terlaksana secara optimal dan tepat sasaran, seperti: 1. Pembagian kelompok kurang merata sehingga tutor sebaya belum berjalan dengan lancar; 2. Siswa belum terlalu fokus dan bersemangat dikarenakan mereka belum lancar dalam membaca; 3. Disaat membaca, suara siswa terdengar sangat pelan yang berakibat siswa lain mengalami kesulitan mendengarnya; 4 . Ada beberapa siswa yang belum hafal tetapi tidak mau menerima bantuan dari teman satu kelompoknya yang hafal; dan 5. Masih ditemukan siswa yang belum mau menghafal dan memilih bermain atau memukulmukul meja.

Hasil pembelajaran pada Siklus I, ditemukan hasil sebagai berikut: Siswa yang sangat hafal $20 \%$, siswa yang hafal $25 \%$, siswa yang kurang hafal $40 \%$, siswa yang tidak hafal $15 \%$. Dari hasil tes yang dilaksanakan masih ditemui siswa yang belum hafal. Hasil observasi terhadap siswa yang belum hafal disebabk oleh belum lancarnya siswa dalam membaca surat An-Nasr. Selain daripada itu, jadwal pelajaran Pendidikan Agama Islam untuk siswa Kelas I disusun secara berurutan tanpa memberikan jeda, menyebabkan siswa mengalami kesulitan jika mereka berlatih menghafal di rumah masing-masing.

Berdasarkan kekurangan-kekurangan dan permsalahan yang mumcul pada Siklus I, maka kegiatan pembelajaran pada Siklus II diperlukan beberapa perubahan yaitu: 1 . guru harus mengoptimalkan cara memotivasi siswa dalam menghafal; 2. guru memberikan bimbingan kepada kelompok maupun individu secara merata; 3. guru melakukan bimbingan dan dorongan kepada siswa untuk menghafal dengan maksimal; dan 4. guru menambah alokasi waktu untuk berlatih, mengubah jadwal yang berurutan.

Pada aktivitas Siklus II, siswa lebih bersemangat dan lebih aktif dan saling berkompetisi secara sehat untuk dapat menyelesaikan tugas dengan tepat waktu. Dari permainan tersebut siswa dapat dengan mudah menghafal surat-surat pendek dikarenakan telah berulang kali dibaca didengar dan diberi kesempatan untuk menghafal secara individu. Pembelajaran melalui Permainan Bendera memberikan rasa senang dan bersemangat untuk menghafal. Guru telah mencoba pembelajaran yang mengaktifkan siswa baik dengan permainan maupun mengembangkan konsep atau hafalan surat. Hasil belajar dari Siklus I dan II menunjukkan adanya peningkatan.

Hasil pembelajaran pada Siklus II, ditemukan hasil sebagai berikut: Siswa yang sangat hafal $65 \%$, siswa yang hafal $30 \%$, siswa yang kurang hafal $5 \%$, siswa yang tidak hafal $0 \%$. Hasil ini menunjukkan peningkatan yang sangat signifikan, karena jumlah siswa yang tidak hafal adalah 0\% dimana pada Siklus I mencapai 16\%. Hasil pengamatan terhadap aktifitas guru secara umum pelaksanaan aktifitas guru dalam pelaksanaan pembelajaran Permainan Bendera telah berjalan baik. Dan hasil dari penelitian terhadap siswa bisa dikatakan sukses. Berikut ini grafik perbandingan antar Siklus hasil belajar Pendidikan Agama Islam melalui Permainan Bendera dapat dilihat pada Gambar 1: 


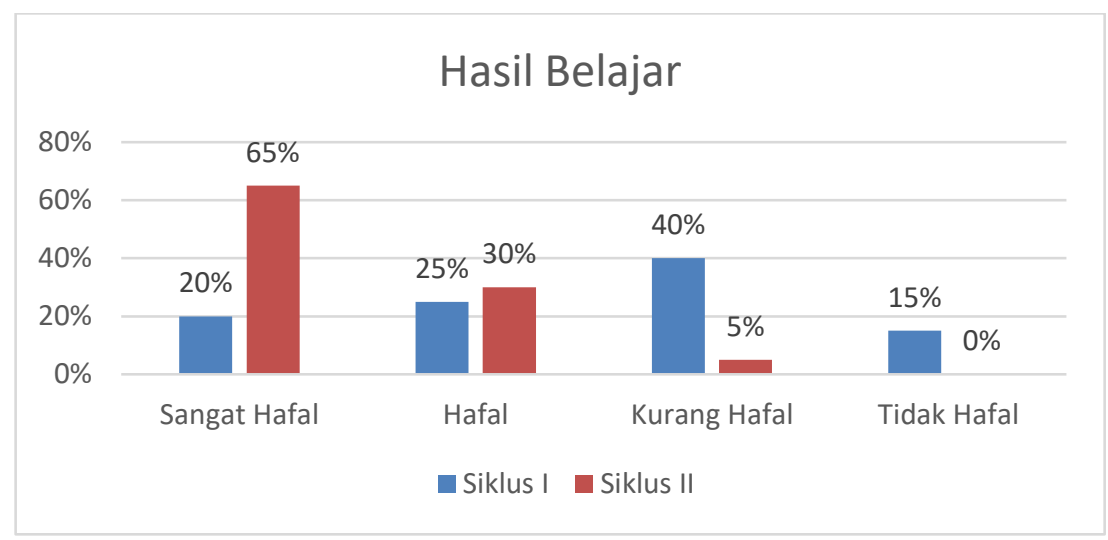

Gambar 1. Grafik Hasil Belajar

\section{Simpulan}

Berdasarkan analisis data mengenai pelaksanaan penelitian tindakan kelas melalui Permainan Bendera surat-surat pendek disimpulkan siswa dalam kegiatan pembelajaran menjadi lebih bersemangat dan lebih aktif dan saling berkompetisi secara sehat untuk dapat menyelesaikan tugas dengan tepat waktu. Dari permainan tersebut siswa dapat dengan mudah menghafal surat-surat pendek dikarenakan telah berulang kali dibaca didengar dan diberi kesempatan untuk menghafal secara individu. Instrumen Permainan Bendera juga meciptkan kegiatan pembelajaran yang tidak membosankan.

Hasil pembelajaran Pendidikan Agama Islam untuk Siklus I sangat hafal (sangat baik) sebesar $20 \%$ dan hafal (baik) sebesar $25 \%$ jumlah keseluruhan yang sangat hafal dan hafal (baik) Siklus I sebesar 45\%. Untuk Siklus II sangat hafal (sangat baik) sebesar $65 \%$ dan yang hafal (baik) sebesar 30\% jumlah keseluruhan yang sangat hafal dan hafal $95 \%$. Hasil penelitian menunjukkan adanya peningkatan hasil belajar Pendidikan Agama Islam melalui metode Permainan Bendera untuk Siklus I siswa hafal ayat-ayat pendek sebesar 45\% dan Siklus II siswa hafal sebesar $95 \%$.

\section{Saran}

Guru diharapkan untuk melakukan pembelajaran metode Permainan Bendera, untuk pembelajaran Pendidikan Agama Islam untuk kelas I. Guru diharapkan mengembangkan pembelajaran yang inovatif, kreatif, interaktif, dan menyenangkan. Oleh karena itu, maka sekolah diharapkan dapat menganjurkan atau mendorong para guru untuk mengembangkan pembelajaran yang inovatif, kreatif, interaktif, dan menyenangkan. Sekolah memberikan fasilitas, baik fisik maupun pengetahuan melalui nara sumber atau bentuk pelatihan yang lainnya. Dan pagi peneliti lain bisa menjadikan jurnal sebagai bahan referensi atau menjadi acuan untuk pengembangan penelitian menggunakan metode ini ketingkat lebih lanjut.

\section{Referensi}

Al Fatihah, M. 2016. Hubungan antar Kemandirian Belajar dengan Prestasi Belajar PAI Siswa Kelas III SDN Panular Surakarta. At-Tanbawi. Volume 1, No. 2, JuliDesember 2016. 197-207

Anegawati, E. 2016. Penerapan Strategi Pemebelajaran Modelling The Way untuk Meningkatkan Hasil Belajar Pendidikan Agama Islam (PAI) Siswa Kelas IV SD Negeri 010 Banjar Panjang Kecamatan Kerumutan. Jurnal Primary Program 
Studi Pendidikan Guru Sekolah Dasar Fakultas Keguruan dan Ilmu Pendidikan Universitas Riau. Volume 5, Nomor 3, Edisi Khusus HUT PGRI Ke-71. 618-632

Aprilianti, R. 2017. Meningkatkan Kemampuan Membilang Angka 1 sampai 20 melalui Permainan Bendera intar pada Anak Usia 5-6 Tahun. Jurnal Golden Age Universitas Hamzanwandi. Vol. 01, No. 2, Desember 2017. 90-102

Ayudia, Suryanto, E., Waluyo, B. 2016. Analisis Kesalahan Penggunaan Bahasa Indonesia dalam Laporan Hasil Observasi pada Siswa SMP. BASASTRA Jurnal Penelitian Bahasa, Sastra Indonesa dan Pengajarannya. Volume 4, Nomor 1, April 2016. 36-49

Dananjaya, U. 2012. Media Pembelajaran Aktif. Bandung: Nuansa

Freeman, J., Munandar, U. 1996. Cerdas dan Cemerlang: Kiat Menemukan dan Mengembangkan Bakat Anak 0-5 Tahun. Jakarta: PT. Gramedia Pustaka Utama.

Nurlina, dkk. 2014. Implementasi Manajemen Pengajaran PAI untuk Meningkatkan Prestasi Belajar Siswa pad SDN Ateuk Kabupaten Aceh Besar. Jurnal Mudarrisuna. Vol. 4, No. 1. 124-135

Nurmayanti, A., Mardhiah, I., Rachmat, N. 2017. Pemanfaatan Internet dalam Meningkatkan Hasil Belajar PAI Siswa (Studi Kasus Siswa Kelas X SMK Negeri 7 Jakarta Timur). Jurnal Studi Al-Qur'an: Membangun Tradisi Berfikir Qur'ani. Vol. 13, No.1. 48-60.

Piaget, J. 1951. The Child's Conception of The World. Maryland: Littlefield Publishers.

Sulasmi. 2014. Peningkatan Hasil Belajar Pendidikan Agama Islam melalui Games Bendera Kelas I.1 SD Negeri Keputran "A”. Jurnal Ilmiah Guru "COPE”. No. 01/Tahun XVIII. 19-25.

Zaenal, M., Kusaeri. 2017. Pengembangan Instrumen Penilaian Tes Terulis Bentuk Uraian untuk Pembekajaran PAI Berbasis Masalah Materi Fiqih. Jurnal Tatsqif. Volume 15, No. 1, Juni 2017. 1-23 